\title{
Quantifying Control Efficacy of Fungicides Commonly Applied for Potato Early Blight Management
}

\author{
S. K. R. Yellareddygari, Raymond J. Taylor, Julie S. Pasche, and Neil C. Gudmestad ${ }^{\dagger}$ \\ Department of Plant Pathology, North Dakota State University, Fargo, ND 58105
}

\begin{abstract}
Early blight is an economically important foliar disease of potato in the United States. Because of the lack of resistant potato cultivars, fungicides are applied extensively to obtain adequate control. To manage early blight, standard protectant fungicides and single-site mode-of-action "specialty" fungicides are applied either alone or incorporated into a fungicide rotation program. Control efficacy at two crop growth stages (tuber initiation/early bulking and late bulking/tuber maturation) and the overall tuber yield response to standard and specialty fungicides were

nontreated control. For both potato growth stages, specialty fungicides performed better than standard protectant fungicides. Furthermore, control efficacy of both fungicides was higher (3 to 9\%) at late bulking and tuber maturation when compared with early bulking crop growth stage. Specialty fungicide programs increased overall tuber yields by 4 and $9 \%$ over standard fungicides and nontreated control, respectively. Based on the results, more precise fungicide use recommendations and fungicide programs can be developed for early blight management.
\end{abstract} assessed using network metaanalytic models. Control efficacy of fungicides ranged from moderate to very high ( $>30$ to $75 \%$ ) compared with the

Keywords: chemical, disease management, field crops, fungi, vegetables

Early blight, caused by the fungus Alternaria solani, is an important foliar disease in several potato-growing regions across the globe. Characteristic foliar symptoms caused by $A$. solani include small discrete lesions with a concentric ring pattern (Franc and Christ 2001; Gudmestad et al. 2013). Later in the growing season, early blight lesions may coalesce, causing defoliation and thus, reducing potato yield (Franc and Christ 2001; Rotem 1994). In some instances, significant yield loss has been reported owing to early blight epidemics (Christ and Maczuga 1989; Olanya et al. 2009; Rotem and Feldman 1965; Shtienberg et al. 1990). A 2018 study demonstrated that relative yield loss owing to early blight severity was higher at the early bulking stage than the late bulking and tuber maturation stage (Yellareddygari et al. 2018).

Fungicide applications are the primary method to manage early blight owing to lack of resistant potato cultivars. Pathogen development and disease establishment can be suppressed by the timely application of foliar fungicides. In the midwestern United States, growers frequently begin applying foliar fungicides before disease inception and continue every 7 to 10 days until the end of potatogrowing season. Standard fungicides, which are less expensive and have a broad spectrum mode of action (e.g., chlorothalonil and mancozeb), are traditionally applied for early blight management (Gudmestad et al. 2013; Holm et al. 2003). However, standard fungicides have reduced efficacy under intense disease pressure conditions, and this has led to increased use of single site-specific mode-of-action fungicides (Gudmestad et al. 2013; Pasche and Gudmestad 2008). Hereafter, single site-specific fungicides will be referred to as "specialty fungicides" owing to their premium price, higher degree of efficacy, and more narrow spectrum of activity on other foliar pathogens when compared with standard protectant fungicides. Specialty fungicides, such as azoxystrobin, pyraclostrobin from the quinone outside inhibitor class (QoI), and boscalid from the succinate dehydrogenaseinhibiting (SDHI) group, have been extensively used for successful management of early blight suppression in the United States

${ }^{\dagger}$ Corresponding author: N. C. Gudmestad; neil.gudmestad@ndsu.edu

The author(s) declare no conflict of interest.

Accepted for publication 23 May 2019.

(C) 2019 The American Phytopathological Society
(Pasche and Gudmestad 2008; Stevenson and James 1999). However, development of resistant mutations in A. solani has rendered specialty fungicides ineffective for the management of early blight in the United States (Bauske et al. 2018a, b; Gudmestad et al. 2013; Mallik et al. 2014; Pasche and Gudmestad 2008; Pasche et al. 2004).

In a 2016 study, the overall efficacy of specialty fungicide-based application programs and standard fungicides was estimated with respect to early blight disease development and potato yield (Yellareddygari et al. 2016). However, this study only demonstrated whether any significant differences existed among specialty-based applications and standard and control treatments for the study parameters of disease development and tuber yield. Actual control efficacy and yield response differences among treatments were not estimated. Control efficacy is the effect of fungicide on early blight control as determined by labeled instructions. A study quantifying the percentage of early blight control owing to standard or specialty fungicide applications will provide additional information that may assist producers in making management decisions. Therefore, the objective of this study was to assess whether there is decline or increase in control efficacy of specialty fungicides compared with standard fungicide programs and resultant tuber yield. The comparisons were made among fungicide treatments applied at the tuber initiation and early bulking or at the late bulking-tuber maturation growth stages.

\section{Materials and Methods}

A total of 12 field trials were conducted in North Dakota and Minnesota from 2003 to 2014 under an overhead irrigation system. The experimental design for all field trials was a randomized complete block design with four replications per treatment. The early blight susceptible cultivar Russet Burbank potato was planted during 2003 to 2007 trials, and susceptible cultivar Ranger Russet was planted in the 2008 to 2014 field trials. All agronomic practices relevant to potato-growing regions of North Dakota and Minnesota were performed by our research group or grower cooperator (Bohl and Johnson 2010). Pathogen inoculations for disease development and subsequent fungicide applications were performed as previously described (Pasche and Gudmestad 2008; Yellareddygari et al. 2016). Experimental units consisted of four rows $\sim 7.0 \mathrm{~m}^{2}$ in size, with disease severity visually assessed at the plot level in four 1-m areas from the center two rows. For 12 trials, disease severity was rated by a single evaluator (R. J. Taylor). Early blight severity was assessed as percentage of foliage (in 1-m areas) showing chlorotic lesions and senescent foliage typical of $A$. solani infections. The percentage of 
early blight severity from four 1-m areas was averaged. As described elsewhere, 11 weekly disease ratings were performed over the cropgrowing season (Yellareddygari et al. 2016, 2018). Disease ratings were low $(<5 \%)$ during vegetative growth and flowering crop growth stages (weeks 1 to 6), and they were not considered for metaanalysis, because the results may be biased (Dalla Lana et al. 2018; Reis et al. 2008). For each trial, weekly ratings were averaged into two stages of potato development: tuber initiation to early bulking (weeks 7 to 9) and late bulking-tuber maturation (weeks 10 and 11) (Miller and Hopkins 2008; Yellareddygari et al. 2018). Therefore, fungicide control efficacy was estimated separately at two growth stages. At the end of the growing season, vines were mechanically flailed, and tuber yield was recorded $\sim 1$ week later. Although disease was measured at two crop growth stages, only overall tuber yield response was estimated relative to treatment applications over the entire growing season.

Selection criteria. Trials included in this study satisfied the criteria of having similar experimental design and treatment types. Overall, 10 fungicide applications were performed during each potato-growing season. Studies evaluating specialty fungicides, standard protectant fungicide, and nontreated control were selected. Furthermore, specialty fungicides were classified based on QoI and SDHI group chemical fungicides; they were always applied in rotation with other fungicide classes and hereafter, will be referred as group 1 and group 2 specialty fungicides, respectively (Table 1). Each specialty group fungicide treatment included three and seven applications of single-site mode-of-action fungicide and standard protectant, respectively.

Overall efficacy and yield response. For each trial, separate linear mixed models were fitted to estimate mean disease severity and yield for all treatments evaluated. In the mixed model, treatment was considered as a fixed effect, and block was considered as a random effect. The estimates and residual variance for each trial were obtained using SAS Mixed procedure (Littell et al. 2006). The treatment estimates and residual variance were used for network metaanalysis (Dalla Lana et al. 2018).

Separate network (multitreatment) metaanalysis was fitted for severity index and yield response after log transformation was applied to the estimated means (Madden and Paul 2011; Paul et al. 2008). The SAS MIXED procedure was used to fit the models as previously described (Madden et al. 2016; Paul et al. 2008). The mixed models can be written as (Dalla Lana et al. 2018):

$$
Y_{i} \sim N\left(\mu \sum+S_{i}\right)
$$

where $Y_{i}$ is the vector of $\log$ mean-transformed mean response (disease severity or yield) for the treatments for the $i$ th study, $N$ represents multivariate distribution, $\mu$ represents the mean $Y_{i}$ across all studies, $\sum$ represents between-study variance matrix, and $S_{i}$ is the within-study variance for the $i$ th study.

The overall log mean response ratios (fungicide to nontreated control) and respective confidence intervals (CIs) were estimated for each fungicide relative to the nontreated control for disease $\left(\bar{L}_{S e v}\right)$ and yield $\left(\bar{L}_{Y l d}\right)$ using estimate statements in Mixed procedure in SAS (Dalla Lana et al. 2018). This procedure was repeated to obtain $\log$ mean response ratios (specialty fungicide to standard fungicide) and respective CIs for the specialty fungicide relative to standard fungicide. Overall mean percentage of early blight disease control $\left(\bar{C}_{S e v}\right)$, tuber yield response $\left(\bar{Y}_{Y l d}\right)$, and their corresponding $95 \%$ CIs were obtained by back transforming the log data (Dalla Lana et al. 2018; Paul et al. 2008). Back transformation is applied for overall mean percentages of early blight control and tuber yield response as $\bar{C}_{S e v}=\left[1-\left(\exp \left(\bar{L}_{S e v}\right)\right] \times 100\right.$ and $\bar{Y}_{Y l d}=\left[1-\left(\exp \left(\bar{L}_{Y l d}\right)\right] \times 100\right.$, respectively. The presence of heterogeneity among studies was not studied, because metaanalysis included only a small number (12) of studies.

\section{Results}

Early bulking crop growth stage. Early blight severity varied considerably among treatments. At early bulking growth stage, the difference between low- and high-severity median values was $25.13 \%$ (Table 2). Disease severity was higher for standard fungicides compared with that of specialty fungicides. Median early blight severity values in nontreated control were $>7$ and $49 \%$ in more than three-quarters and one-quarter of the studies, respectively.

Network metaanalysis results demonstrated that all fungicide treatments significantly reduced early blight disease severity compared with the nontreated control $\left(\bar{L}_{S e v}<0 ; P\right.$ value $\left.<0.05\right)$ (Table 3$)$. Compared with standard fungicides, specialty-based fungicide applications significantly lowered early blight disease severity $\left(\bar{L}_{S e v}<0\right.$; $P$ value $<0.05)$. Estimates of mean disease control efficacy $\bar{C}_{S e v}$ (obtained after back transforming $\bar{L}_{S e v}$ ) were high (>64\%) for specialty fungicides compared with the nontreated control followed by comparison with standard fungicides $(>30 \%)$. Standard fungicide applications resulted in $49 \%$ improved control compared with the nontreated control.

Late bulking and tuber maturation crop growth stage. Early blight severity and yield response varied substantially among treatments and trials. Median disease severity and yield among treatments ranged from 18.25 to $90.93 \%$ and from 55.35 to $59.95 \mathrm{mt} / \mathrm{ha}$, respectively (Table 2). The difference between low- and high-severity median values was $72.68 \%$, and maximum and minimum yields differed by $5.25 \mathrm{mt} / \mathrm{ha}$. Median early blight severity values in the nontreated control were $>36$ and $99 \%$ in more than three-quarters and one-quarter of the studies, respectively. Also, tuber yields were $>48$ and $<60 \mathrm{mt} / \mathrm{ha}$ in three-quarters and one-quarter of the studies, respectively.

During late bulking and tuber maturation stage, all treatment applications significantly lowered disease severity when compared with the nontreated control $\left(\bar{L}_{S e v}<0 ; P\right.$ value $\left.<0.05\right)$ (Table 4). Furthermore, specialty-based fungicides significantly reduced early blight disease severity compared with standard fungicide $\left(\bar{L}_{S e v}<0 ; P\right.$ value $<0.05)$. Mean disease control estimates $\left(\bar{C}_{S e v}\right)$ of all fungicides

Table 1. Treatments evaluated in a network metaanalysis of 12 field trials conducted in North Dakota and Minnesota from 2003 to $2014^{\mathrm{a}}$

\begin{tabular}{lll}
\hline Year & \multicolumn{1}{c}{ SF group 1 (active ingredient) } & \multicolumn{1}{c}{ SF group 2 (active ingredient) } \\
\hline 2003 & Pyraclostrobin + mancozeb & Boscalid + mancozeb \\
2004 & Famoxadone + mancozeb & Boscalid + chlorothalonil \\
2005 & Pyraclostrobin + pyremethanil + chlorothalonil & Boscalid + famoxadone + chlorothalonil \\
2006 & Famoxadone + pyremethanil + mancozeb & Boscalid + pyraclostrobin + chlorothalonil \\
2007 & Pyraclostrobin + pyremethanil + chlorothalonil & Boscalid + famoxadone + mancozeb \\
2008 & Pyraclostrobin + pyremethanil + mancozeb & Boscalid + famoxadone + mancozeb \\
2009 & Pyraclostrobin + pyremethanil + mancozeb & Difenoconazole + mandipropamid + chlorothalonil \\
2010 & Fenamidone + pyremethanil + chlorothalonil & Difenoconazole + mandipropamid + chlorothalonil \\
2011 & Fenamidone + pyremethanil + chlorothalonil & Difenoconazole + mandipropamid + chlorothalonil \\
2012 & Fenamidone + pyremethanil + chlorothalonil & Boscalid + famoxadone + mancozeb \\
2013 & Fenamidone + pyremethanil + chlorothalonil & Boscalid + pyraclostrobin + chlorothalonil \\
2014 & Fenamidone + pyremethanil + chlorothalonil & Fluopyram + pyremethanil + mancozeb \\
\hline
\end{tabular}

a The plus sign indicates alternation with fungicides with different active ingredients. There was nontreated treatment for all trials. SF, specialty fungicide; $\mathrm{StdF}$, standard fungicide. 
Table 2. Summary statistics for early blight severity and tuber yield for treatments evaluated in a network metaanalysis of 12 field trials conducted in North Dakota and Minnesota from 2003 to 2014 using cultivars Russet Burbank and Ranger Russet ${ }^{\mathrm{a}}$

\begin{tabular}{|c|c|c|c|c|c|c|c|c|c|c|}
\hline \multirow[b]{2}{*}{ Fungicide: code and active ingredient } & \multirow[b]{2}{*}{$N$} & \multicolumn{3}{|c|}{$\begin{array}{c}\text { Severity }(\%) \text { at tuber } \\
\text { initiation-early bulking }\end{array}$} & \multicolumn{3}{|c|}{$\begin{array}{l}\text { Severity (\%) late bulking- } \\
\text { tuber maturation }\end{array}$} & \multicolumn{3}{|c|}{ Yield (mt/ha) } \\
\hline & & Median & Q1 & Q3 & Median & Q1 & Q3 & Median & Q1 & Q3 \\
\hline \multicolumn{11}{|l|}{ Nontreated } \\
\hline- & 48 & 30.2 & 7.4 & 49.6 & 90.9 & 36.3 & 99.7 & 55.4 & 48.7 & 59.5 \\
\hline \multicolumn{11}{|l|}{ SF group 1} \\
\hline $\begin{array}{l}\text { Pyraclostobin/famoxadone }+ \text { fenamidone }+ \\
\text { pyrimethanil + chlorothalonil/mancozeb }\end{array}$ & 48 & 5.4 & 2.5 & 9.3 & 18.3 & 5.3 & 85.6 & 60.0 & 52.9 & 64.3 \\
\hline \multicolumn{11}{|l|}{ SF group 2} \\
\hline $\begin{array}{l}\text { Boscalid/fluopyram }+ \text { pyrimethanil }+ \\
\text { difenoconazole }+ \text { pyraclostrobin/ } \\
\text { famoxadone }+ \text { chlorothalonil/mancozeb }\end{array}$ & 48 & 5.0 & 1.3 & 8.4 & 23.9 & 5.3 & 91.5 & 58.6 & 54.7 & 61.9 \\
\hline \multicolumn{11}{|l|}{ StdF } \\
\hline Chlorothalonil/mancozeb & 48 & 8.3 & 3.8 & 22.6 & 39.1 & 11.6 & 95.8 & 55.9 & 50.2 & 61.4 \\
\hline
\end{tabular}

Table 3. Effect size estimates, associated statistics, and percentage disease control of potato early blight for fungicides applied at early bulking growth stage evaluated in 12 field trials conducted from the 2003 to the 2014 potato crop-growing seasons

\begin{tabular}{|c|c|c|c|c|c|c|c|c|}
\hline \multirow[b]{2}{*}{ Fungicide $^{\mathbf{a}}$} & \multicolumn{5}{|c|}{ Effect size $^{b}$} & \multicolumn{3}{|c|}{ Percentage disease controlc } \\
\hline & $\bar{L}_{S e v}$ & SE & $C I_{\text {Lower }}$ & $\boldsymbol{C I}_{\text {Upper }}$ & $P$ value & $\bar{C}_{S e v}$ & $Y_{\text {Lower }}$ & $Y_{U p p e r}$ \\
\hline $\mathrm{SF} 1$ versus $\mathrm{Ctl}$ & -1.069 & 0.240 & -1.557 & -0.581 & $<0.0001$ & 65.67 & 78.93 & 44.07 \\
\hline $\mathrm{SF} 2$ versus $\mathrm{Ctl}$ & -1.034 & 0.244 & -1.531 & -0.538 & 0.0002 & 64.45 & 78.37 & 41.59 \\
\hline StdF versus Ctl & -0.672 & 0.209 & -1.098 & -0.247 & 0.0029 & 48.94 & 66.64 & 21.85 \\
\hline SF1 versus StdF & -0.397 & 0.135 & -0.672 & -0.122 & 0.006 & 32.77 & 48.95 & 11.47 \\
\hline $\mathrm{SF} 2$ versus $\mathrm{StdF}$ & -0.362 & 0.143 & -0.653 & -0.071 & 0.0163 & 30.39 & 47.97 & 6.86 \\
\hline
\end{tabular}

${ }^{a} \mathrm{Ctl}$, nontreated control; SF1, specialty fungicide group 1; SF2, specialty fungicide group 2; StdF, standard fungicide.

${ }^{\mathrm{b}}$ Overall mean log response ratios $\left(\bar{L}_{S e v}\right)$ for the effect of treatment versus treatment comparison on early blight severity, associated standard error (SE), lower $\left(C I_{\text {Lower }}\right)$ and upper $\left(C I_{U_{\text {pper }}}\right)$ limits of the $95 \%$ confidence interval, and probability value ( $P$ value).

${ }^{\mathrm{c}}$ Mean percentage control $\left(\bar{C}_{S e v}\right)$ estimated by back transforming $\left(\bar{L}_{S e v}\right)$ and associated lower $\left(Y_{\text {Lower }}\right)$ and upper $\left(Y_{U p p e r}\right)$ limits of the $95 \%$ confidence interval.

Table 4. Effect size estimates, associated statistics, and percentage disease control of potato early blight for fungicides applied at late bulking and tuber maturation growth stage in 12 field trials conducted from the 2003 to 2014 potato crop-growing seasons

\begin{tabular}{|c|c|c|c|c|c|c|c|c|}
\hline \multirow[b]{2}{*}{ Fungicide $^{\mathbf{a}}$} & \multicolumn{5}{|c|}{ Effect size ${ }^{b}$} & \multicolumn{3}{|c|}{ Percentage disease control ${ }^{c}$} \\
\hline & $\bar{L}_{S e v}$ & SE & $C I_{\text {Lower }}$ & $C I_{\text {Upper }}$ & $P$ value & $\overline{\bar{C}_{S e v}}$ & $Y_{\text {Lower }}$ & $Y_{\text {Upper }}$ \\
\hline $\mathrm{SF} 1$ versus $\mathrm{Ctl}$ & -1.372 & 0.131 & -1.639 & -1.105 & $<0.0001$ & 74.65 & 80.59 & 66.88 \\
\hline $\mathrm{SF} 2$ versus $\mathrm{Ctl}$ & -1.423 & 0.174 & -1.776 & -1.070 & $<0.0001$ & 75.90 & 83.07 & 65.69 \\
\hline StdF versus Ctl & -0.733 & 0.143 & -1.024 & -0.441 & $<0.0001$ & 51.93 & 64.09 & 35.65 \\
\hline SF1 versus $\mathrm{StdF}$ & -0.640 & 0.110 & -0.864 & -0.415 & $<0.0001$ & 47.25 & 57.85 & 33.99 \\
\hline SF2 versus $\mathrm{StdF}$ & -0.690 & 0.160 & -1.015 & -0.366 & 0.0001 & 49.86 & 63.77 & 30.62 \\
\hline
\end{tabular}

${ }^{\text {a }}$ Ctl, nontreated control; SF1, specialty fungicide group 1; SF2, specialty fungicide group 2; StdF, standard fungicide.

${ }^{\mathrm{b}}$ Overall mean $\log$ response ratios $\left(\bar{L}_{S e v}\right)$ for the effect of treatment versus treatment comparison on early blight severity, associated standard error (SE), lower $\left(C I_{\text {Lower }}\right)$ and upper $\left(C I_{U p p e r}\right)$ limits of the $95 \%$ confidence interval, and probability value $(P$ value $)$.

${ }^{\mathrm{c}}$ Mean percentage control $\left(C_{S e v}\right)$ estimated by back transforming $\left(\bar{L}_{S e v}\right)$ and associated lower $\left(Y_{\text {Lower }}\right)$ and upper $\left(Y_{U p p e r}\right)$ limits of the $95 \%$ confidence interval.

Table 5. Effect size estimates, associated statistics, and calculated tuber yield response for fungicides evaluated in 12 field trials conducted from the 2003 to 2014 potato crop-growing seasons

\begin{tabular}{|c|c|c|c|c|c|c|c|c|}
\hline \multirow[b]{2}{*}{ Fungicide ${ }^{a}$} & \multicolumn{5}{|c|}{ Effect size $^{\mathbf{b}}$} & \multicolumn{3}{|c|}{ Yield response $^{c}$} \\
\hline & $\bar{L}_{Y l d}$ & $\mathbf{S E}$ & $C I_{\text {Lower }}$ & $C I_{\text {Upper }}$ & $P$ value & $\overline{\boldsymbol{Y}}_{Y l d}$ & $Y_{\text {Lower }}$ & $Y_{\text {Upper }}$ \\
\hline SF1 versus Ctl & 0.089 & 0.013 & 0.062 & 0.116 & $<0.0001$ & 9.29 & 6.37 & 12.28 \\
\hline $\mathrm{SF} 2$ versus $\mathrm{Ctl}$ & 0.090 & 0.014 & 0.060 & 0.119 & $<0.0001$ & 9.40 & 6.22 & 12.67 \\
\hline StdF versus $\mathrm{Ctl}$ & 0.047 & 0.012 & 0.023 & 0.071 & 0.0004 & 4.81 & 2.29 & 7.40 \\
\hline SF1 versus StdF & 0.042 & 0.008 & 0.026 & 0.058 & $<0.0001$ & 4.27 & 2.59 & 5.98 \\
\hline SF2 versus $\mathrm{StdF}$ & 0.043 & 0.010 & 0.023 & 0.063 & 0.0001 & 4.37 & 2.30 & 6.49 \\
\hline
\end{tabular}

${ }^{a} \mathrm{Ctl}$, nontreated control; SF1, specialty fungicide group 1; SF2, specialty fungicide group 2; StdF, standard fungicide.

b Overall mean log response ratios $\left(\bar{L}_{Y l d}\right)$ for the effect of treatment versus treatment comparison on early blight severity, associated standard error (SE), lower $\left(C I_{\text {Lower }}\right)$ and upper $\left(C I_{\text {Upper }}\right)$ limits of the $95 \%$ confidence interval, and probability value ( $P$ value).

${ }^{\mathrm{c}}$ Mean percentage control $\left(\bar{Y}_{Y l d}\right)$ estimated by back transforming $\left(\bar{L}_{Y l d}\right)$ and associated lower $\left(Y_{\text {Lower }}\right)$ and upper $\left(Y_{\text {Upper }}\right)$ limits of the $95 \%$ confidence interval. 
increased by $>9 \%$ when compared with treatments applied at early bulking crop growth stage. At this growth stage, specialty-based applications resulted in 47 to $49 \%$ estimated mean control efficacy compared with standard fungicides. All fungicides resulted in higher mean control efficacy ( $>50 \%)$ compared with the nontreated control.

Tuber yield response was also significantly increased by all fungicides compared with nontreated control $\left(\bar{L}_{Y l d}>0 ; P\right.$ value $\left.<0.05\right)$ (Table 5). Potato tuber yields were increased significantly for specialtybased fungicides relative to standard fungicides. Specialty-based applications and standard fungicides demonstrated $>9$ and $5 \%$ overall tuber yield response relative to the nontreated control, respectively. Also, specialty-based fungicides resulted in a 4.2 to $4.3 \%$ higher yield response compared with standard fungicides.

\section{Discussion}

This is the first attempt to quantify percentages of disease control efficacy between standard protectants and specialty-based fungicide application programs for potato early blight management. From a disease management and crop economics standpoint, the results are important for growers and researchers in making appropriate recommendations for timely fungicide applications to maximize effective disease control and economic return.

Percentage control efficacy of fungicides at both potato growth stages was significantly different when compared with the nontreated control. This high percentage ( $>30$ to $75 \%$ ) of disease control indicates that a fungicide application is warranted throughout the potato-growing season for adequate management of early blight. Several fungicides categorized into various chemical groups are readily available for disease management. For both crop stages, specialty-based fungicide application programs have superior performance in combating early blight. Overall, efficacy control of specialty fungicides is 29 to $35 \%$ higher than standard protectant fungicides. The higher cost of specialty fungicides may be negligible owing to their high-percentage control of disease severity when compared with less expensive standard protectant fungicides. A detailed cost-benefit analysis on the economics of fungicide costs versus yield benefits is warranted, because it is likely influenced by the specific market sector (table versus process) within the potato industry.

Compared with the early bulking growth stage, standard protectant fungicides and specialty group fungicides applied at late bulking crop growth stages resulted in 3 and $10 \%$ greater early blight control than the nontreated control, respectively. This indicates that treatments significantly improved disease control even under high-disease pressure conditions. Early blight severity is high later in the growing season when senescing leaves/plants are easily infected, resulting in necrosis (Holm et al. 2003). Furthermore, specialty-based fungicide applications significantly outperformed standard fungicides, having $17 \%$ higher efficacy at late bulking and tuber maturation growth stage. This indicates that specialty-based fungicide application continues to be effective until the end of the crop -growing season. However, a previous study predicted that yield loss owing to early blight severity at early bulking crop stage is $13 \%$ higher than during the late bulking growth stage (Yellareddygari et al. 2018). Despite the fact that both fungicide groups have high early blight control efficacy at the late bulking crop growth stage, it is not surprising that the timing of fungicide applications at early bulking crop stage is critical for maximizing tuber yield, because this foliage has the highest potential for accumulating dry matter compared with senescing foliage later in the growing season.

Fungicide applications increased tuber yields by 4 to $9 \%$ compared with the nontreated control. Also, tuber yield significantly improved by $4 \%$ for specialty fungicide groups compared with standard protectant fungicides. The improved disease control and higher tuber yields are consistent with previous study results, demonstrating an inverse relationship between early blight and yield (Yellareddygari et al. 2016, 2018). Improved yields may be the direct result of fungicide application minimizing the loss of green area of the leaf and thereby, improving plants' ability to photosynthesize and store tuber constituents (Horsfield et al. 2010). Future studies analyzing the overall control efficacy and tuber yields separately for each specialty fungicide may provide detailed information on benefits of fungicide rotation programs.
In the study reported here, it is clear that specialty fungicides in rotation with other fungicides result in significant improvement of early blight disease control as well as an increased tuber yield response. Fungicide rotation programs are necessary to manage early blight severity below a level that substantially impacts yield (Yellareddygari et al. 2016). Furthermore, continuous monitoring of resistance in the pathogen populations is key for safeguarding existing fungicides and recommending new fungicide rotation programs.

\section{Literature Cited}

Bauske, M., Mallik, I., Yellareddygari, S. K. R., and Gudmestad, N. C. 2018a Spatial and temporal distribution of mutations conferring QoI and SDHI resistance in Alternaria solani across the United States. Plant Dis. 102:349-358.

Bauske, M., Yellareddygari, S. K. R., and Gudmestad, N. C. 2018b. Potential impact of fluopyram on the frequency of the D123E mutation in Alternaria solani. Plant Dis. 102:656-665.

Bohl, W. H., and Johnson, S. B. 2010. Commercial potato production in North America. Ext. Sect. Potato Assoc. Am. 57:1-85.

Christ, B. J., and Maczuga, S. A. 1989. The effect of fungicide schedules and inoculum levels on early blight severity and yield of potato. Plant Dis. 73:695-698.

Dalla Lana, F., Paul, P. A., Godoy, C. V., Utimada, C. M., da Silva, L. H., Siqueri, F. V., Forcelini, C. A., Jaccoud-Filho, D. S., Miguel-Wruck, D. S., Borges, E. P., Juliatti, F. C., Campos, H. D., Nunes Jr, J., Carneiro, L. C., Canteri, M. G., Ito, M. F., Meyer, M. C., Martins, M. C., Balardin, R. S., Furlan, S. H., Carlin, V. J., and Del Ponte, E. M. 2018. Meta-analytic modelling of the decline in performance of fungicides for managing soybean rust after a decade of use in Brazil. Plant Dis. 102:807-817.

Franc, G. D., and Christ, B. J. 2001. Early blight. Pages 22-23 in: Compendium of Potato Diseases. W. R. Stevenson, R. Loria, G. D. Franc, and D. P. Weingartner, eds. American Phytopathological Society Press, St. Paul, MN.

Gudmestad, N. C., Arabiat, S., Miller, J. S., and Pasche, J. S. 2013. Prevalence and impact of SDHI fungicide resistance in Alternaria solani. Plant Dis. 97:952-960.

Holm, A. L., Rivera, V. V., Secor, G. A., and Gudmestad, N. C. 2003. Temporal sensitivity of Alternaria solani to foliar fungicides. Am. J. Potato Res. 80:33-40.

Horsfield, A., Wicks, T., Davies, K., Wilson, D., and Paton, S. 2010. Effect of fungicide use strategies on the control of early blight (Alternaria solani) and potato yield. Australas. Plant Pathol. 39:368-375.

Littell, R. C., Milliken, G. A., Stroup, W. W., Wolfinger, R. D., and Oliver, S. 2006. SAS for Mixed Models, 2nd Ed. SAS Institute, Cary, NC.

Madden, L. V., and Paul, P. A. 2011. Meta-analysis for evidence synthesis in plant pathology: An overview. Phytopathology 101:16-30.

Madden, L. V., Piepho, H. P., and Paul, P. A. 2016. Statistical models and methods for network meta-analysis. Phytopathology 106:792-806.

Mallik, I., Arabiat, S., Pasche, J. S., Bolton, M. D., Patel, J. S., and Gudmestad, N. C. 2014. Molecular characterization and detection of mutations associated with resistance to succinate dehydrogenase-inhibiting fungicides in Alternaria solani. Phytopathology 104:40-49.

Miller, J. S., and Hopkins, B. G. 2008. Checklist for a holistic potato health management plan. Pages 7-10 in: Potato Health Management, 2nd Ed. D. A. Johnson, ed. American Phytopathological Society Press, St. Paul, MN.

Olanya, O. M., Honeycutt, C. W., Larkin, R. P., Griffin, T. S., He, Z., and Halloran, J. M. 2009. The effect of cropping systems and irrigation management on development of potato early blight. J. Gen. Plant Pathol. 75:267-275.

Pasche, J. S., and Gudmestad, N. C. 2008. Prevalence, competitive fitness and impact of the F129L mutation in Alternaria solani in the United States. Crop Prot. 27:427-435.

Pasche, J. S., Wharam, C., and Gudmestad, N. C. 2004. Shift in sensitivity of Alternaria solani in response to QoI fungicides. Plant Dis. 88:181-187.

Paul, P. A., Lipps, P. E., Hershman, D. E., McMullen, M. P., Draper, M. A., and Madden, L. V. 2008. Efficacy of traizole-based fungicides for fusarium head blight and deoxnivalenol control in wheat: A multivariate meta-analysis. Phytopathology 98:999-1011.

Reis, E. M., Casa, R. T., and Bevilaqua, L. C. 2008. Modelos de ponto critic para estimar danos causados pela ferrugem da folha da aveia branca. Summa Phytopathol. 34:238-241.

Rotem, J. 1994. The Genus Alternaria: Biology, Epidemiology and Pathogenicity. American Phytopathological Society Press, St. Paul, MN.

Rotem, J., and Feldman, S. 1965. The relation between the ratio of yield to foliage and the incidence of early blight in potato and tomato. Isr. J. Agric. Res. 15:115-122.

Shtienberg, D., Bergeron, S. N., Nicholson, A. G., Fry, W. E., and Ewing, E. E. 1990. Development and evaluation of a general model for yield loss assessments in potatoes. Phytopathology 80:466-472.

Stevenson, W. R., and James, R. V. 1999. Evaluation of fungicides to control early blight and late blight of potato-Hancock, 1998. Fungic. Nematic. Tests 54: 212-213.

Yellareddygari, S. K. R., Pasche, J. S., Taylor, R. J., and Gudmestad, N. C. 2016. Individual participant data meta-analysis comparison of foliar fungicides applied for potato early blight management. Plant Dis. 100:200-206.

Yellareddygari, S. K. R., Taylor, R. J., Pasche, J. S., Zhang, A., and Gudmestad, N. C. 2018. Predicting potato tuber yield loss due to early blight severity in the Midwestern United States. Eur. J. Plant Pathol. 152:71-79. 